Soressi, G.P. 1975. New spontaneous or chemically-induced fruit ripening tomato mutants. Tomato. Genet. Coop. Rep. 25:21-2.

Tacket, C.O., H.S. Mason, G. Losonsky, M.K. Estes, M.M. Levine, and C.J. Arntzen. 2000. Human immune responses to a novel Norwalk virus vaccine delivered in transgenic potatoes. J. Infec. Dis. 182:302-305.

Tanksley S., M. Ganal, J. Prince, C. deVincente, M. Bonierbale, P. Broun, T. Fulton, J. Giovannoni, S. Grandillo, G. Martin, R. Messeguer, J. Miller, L. Miller, A. Paterson, O. Pineda, M. Roder, R. Wing, W. Wu, and N. Young. 1992. High density molecular maps of the tomato and potato genomes. Genetics 132:1141-1160.

Theologis, A., P.W. Oeller, L.M. Wong, W.H. Rottmann, and D.M. Gantz. 1993. Use of a tomato mutant constructed with reverse genetics to study fruit ripening, a complex developmental process. Dev. Gen. 14:282-95.

Tigchelaar, E., W. McGlasson, and R. Buescher. 1978. Genetic regulation of tomato fruit ripening. HortScience 13:508-13.

Walmsley, A.M. and C.J. Arntzen. 2000. Plants for delivery of edible vaccines. Current Opinion in Biotech. 11:126-129.

Wann, E.V., E.L. Jourdain, R. Pressey, and B.G. Lyon. 1985. Effect of mutant genotypes $h p o g^{c}$ and $d g \mathrm{og}^{c}$ on tomato fruit quality. J. Amer. Soc. Hort. Sci. 110:212-215.

Wilkinson, J., M. Lanahan, H. Yen, J. Giovannoni, and H. J. Klee. 1995. An ethylene-inducible component of signal transduction encoded by Neverripe. Science 270:1807-9.

Ye, X., B.S. Al, A. Kloti, J. Zhang, P. Lucca, P. Beyer, and I. Potrykus. 2000. Engineering the provitamin A (beta-carotene) biosynthetic pathway into (carotenoid-free) rice endosperm. Science 287:303-305.

Yen, H., S. Lee, S. Tanksley, M. Lanahan, H.J. Klee, and J.J. Giovannoni. 1995. The tomato Never-ripe locus regulates ethylene-inducible gene expression and is linked to a homologue of the Arabidopsis ETRl gene. Plant Physiol. 107:1343-53.

Yen, H., B. Shelton, L. Howard, J. Vrebalov, and J.J. Giovannoni. 1997. The tomato high pigment $(h p)$ locus maps to chromosome 2 and influences plastome copy number and fruit quality. Theor. Appl. Gen. 95:1069-79.

Yochum, L.A., A.R. Folsom, and L.H. Kushi. 2000. Intake of antioxidant vitamins and risk of death from stroke in postmenopausal women. Amer. J. Clin. Nut. 72:476-483.

\title{
Molecular Biology of Host-Pathogen Interactions in Harvested Horticultural Crops
}

\author{
T.G. McCollum \\ USDA, ARS, USHRL, Ft. Pierce, FL 34945
}

\begin{abstract}
Decay caused by fungal plant pathogens can lead to considerable postharvest losses. Estimates of postharvest losses due to decay vary widely with commodity, production area, and season, but it is well known that these losses can be significant (Burchill and Maude, 1986; Eckert 1975; Pathak, 1997). Fungicides, applied both pre- and postharvest, along with environmental management are utilized to minimize postharvest decay. About 50 million pounds of fungicides are applied to fruits and vegetables annually, and it is generally accepted that production and marketing of these products would not be possible without the use of fungicides (Ragsdale and Sisler, 1994). However, public concern over the freedom of fresh fruits and vegetables from pesticides, increasing regulatory constraints for the registration of pesticides, and the development of resistance to fungicides indicate that the availability and use of fungicides is certain to diminish (Ragsdale and Sisler, 1994; Sutton, 1996). The potential loss of fungicides necessitates that alternative strategies must be developed for reducing losses due to postharvest decay.
\end{abstract}

Fortunately, freedom from decay is the norm, rather than the exception. Of the $>100,000$ species of fungi, $<10 \%$ are plant pathogens and $<100$ species of fungi are responsible for the majority of postharvest diseases (Eckert and Ratnayake, 1983). Although some plant pathogens, such as Botrytis cinerea and Colletotrichum sp., have wide host ranges, most fungal species responsible for postharvest decay have a limited number of hosts from related plant species. For example, Penicillium digitatum causes green mold on citrus fruits, but does not cause disease in apples and pears. Penicillium expansum attacks apples and pears, but not citrus fruits. These are examples of "non-host resistance." Non-host resistance is the consequence of: 1) inability of the fungus to recognize and infect the potential host or 2) the ability of the plant to rapidly and successfully activate defense responses (Kombrink and Somssich, 1995).

Unfortunately, when fruits and vegetable tissues are harvested, their resistance to decay is compromised. Injuries incurred during harvesting and handling operations provide ports of entry for pathogens that cannot penetrate unaltered tissues directly. Harvesting initiates senescence even in physiologically immature organs, and ripening is a specialized form of senescence unique to fruits. Consequences of senescence include both the loss of preformed barriers to pathogens as well as a decrease in the ability to mount an active defense. As a result, the incidence of decay increases (Labavitch, 1998). Many

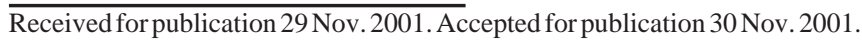

postharvest diseases result from infections that occur early in the life of the fruit, but which remain quiescent until ripening commences (Eckert and Ranayake, 1983; Prusky, 1996). Understanding how natural defense mechanisms are regulated and how to maintain them in harvested products may provide the basis for new strategies to reduce postharvest losses caused by pathogens.

Considerable progress has been made in understanding the interaction between pathogen and host, as evidenced by numerous recent reviews on various aspects of the subject (Dixon and Lamb, 1990; Dixon et al., 1994; Hahn, 1996; Keen, 1992; Knogge, 1996). For the purpose of this review I have chosen to limit my discussion primarily to responses induced in the pathogen by the host and in the host by the pathogen. In addition, in keeping with the theme of the colloquium, I have chosen to focus on studies conducted specifically with harvested horticultural crops in order to illustrate concepts regarding molecular aspects of the host-pathogen interaction.

\section{THE PATHOGEN}

The first step in the infection process is recognition of the host by the pathogen, and this is no doubt regulated by signals arising from the host. Various chemical signals from the host have been identified as being stimulatory to germination of the pathogen. Volatiles emitted from wounded oranges stimulate the germination of $P$. digitatum conidia (Eckert and Ratnayake, 1994). Ethylene has also been suggested as a host-generated signal that stimulates fungal germination. Flaishman and Kolattukudy (1994) reported that ethylene at concentrations $\leq 1 \mathrm{ppm}$ caused germination, branching of the germ tube, and formation of up to six appressoria from single spores of Colletotrichum gloeosporioides. Colletotrichum gloeosporioides formed multiple appressoria on wild-type tomato fruit, but not on transgenic tomatoes that lacked the capacity to produce ethylene. Treatment of inoculated transgenic fruit with ethylene resulted in infection and lesion development (Flaishman and Kolattukudy, 1994). Sensitivity of Diplodia natalensis to scoporone, an antifungal compound in citrus rind, was reduced and fungal growth rate was increased when the fungus was grown in the presence of ethylene (Brown and Lee, 1993).

Compounds present in the cuticle have also been shown to stimulate the germination and germ tube growth of pathogens. Surface waxes from avocado stimulate germination and formation of appressoria from the spores of $C$. gloeosporioides. Reciprocally, waxes from nonhost species do not induce appressoria. Furthermore, avocado wax 
does not induce appressoria formation in most Colletotrichum species that do not infect avocado (Podila et al., 1993). Hwang et al. (1995) cloned a gene, Cap50 from Colletotrichum, that is expressed uniquely during appressorium formation induced by host cuticular waxes. Transcripts for the gene were detected at the infection front in tomato fruit infected by $C$. gloeosporioides, whereas mutants of the fungus that did not express the gene had decreased virulence on tomato and avocado fruits (Hwang et al., 1995).

To establish an infection, pathogens must first overcome the physical barriers of the cuticle and cell wall. As was mentioned previously, harvesting and handling frequently lead to injuries that provide ports of entry for pathogens ordinarily not capable of penetrating the host directly, but some fungi have developed sophisticated ways to penetrate plant tissues directly with an appressorium from which an infection peg extends into the host (Prusky, 1996).

Cutin represents the first barrier to infection presented by intact plant tissues, and cutinase has been proposed as being essential for infection of plant tissue although the evidence is not conclusive. Strong evidence for the involvement of cutinase in plant-pathogen interactions was obtained by the insertion of a cutinase gene, derived from the pea pathogen Fusarium solani f. sp. pisi, into Mycosphaerella sp., a wound pathogen of papaya fruits. Transformants of this pathogen were able to directly penetrate papaya fruit through the non-wounded cuticle (Dickman et al., 1989). However, van Kan et al. (1997) developed mutants of Botrytis cinerea deficient in cutinase A and tested the ability of the mutants to infect gerbera flowers and tomato fruit. These authors reported that the cutinase-deficient mutants were able to infect the host tissues, suggesting that cutinase is not required for infection of these hosts by this pathogen. Bostock et al. (1999) reported that chlorogenic and caffeic acids inhibited cutinase production by Monilinia fructicola and that resistance of peach fruit to infection by $M$. fructicola was positively correlated with levels of these two phenolic acids.

Once a pathogen has gained entry into the plant, it must still disrupt the cell wall in order to colonize the host. Fungal pathogens secrete a cocktail of hydrolases that are capable of digesting the host cell wall (Walton, 1994). These enzymes include cellulases, pectinases, xylanases, and proteases. The requirement of these enzymes for pathogenicity, like that of cutinase, is not equivocal; however, it is generally accepted that they play a role in the colonization process. Wattad et al. (1997) reported that $C$. gloeosporioides, when infecting avocado fruit, produces pectate lyase and that the highest amount of enzyme was detected at the leading edge of lesions. In addition, mixing conidia of $C$. gloeosporioides with antibodies raised against pectate lyase inhibited the development of the pathogen, indicating the importance of the enzyme in pathogenicity. Elimination of Botrytis cinerea polygalacuturonase 1 (PG1) by partial gene replacement resulted in mutants that were still capable of infecting tomato fruit, but with a significant reduction in growth of lesions (ten Have et al., 1998). These results indicate that the PG1 is required for full virulence of this pathogen. Part of the problem in identifying the role of pathogen cell wall-digesting enzymes is that pathogens produce numerous isoforms of these enzymes (Walton, 1994) and elimination of a single isoform may be compensated by the pathogen (Walton, 1994).

Cell wall-degrading enzymes are not only important for the pathogen to breach the plant cell wall, they are also involved in the generation of signals that are components of the recognition process by which the plant senses the presence of a pathogen (Walton, 1994). This recognition is a prerequisite for the activation of the plant's own defense program. Plants do not recognize the extracellular cell wall hydrolases directly, but rather respond to the products generated by their action (Walton, 1994). Proteins capable of inhibiting fungal PG (PG inhibitor protein, PGIP) have been detected in all plant tissues investigated. Conceptual and correlative evidence suggests that PGIPs have a role in plant defense. Two possible mechanisms of PGIP in defense are: 1) directly limiting the action of fungal PG and thereby reducing pathogenicity; or 2) modifying the action of fungal PGs so that products are generated that serve as elicitors of plant defense reactions (Labavitch, 1998). There is some evidence suggesting that the presence of PGIP can influence the fungal production of PGs, and that, in the presence of PGIP, fungi compensate by producing more of the PGs that are resistant to the inhibitor (Labavitch, 1998).
The role of PGIP in disease resistance remains questionable (Labavitch et al., 1998). Labavitch (1998) has proposed that PGIP is just one component of the defense response in plants, and that a clear understanding of how the inhibitor interacts with its target and whether the interaction contributes to the activation of other host responses is lacking.

\section{THE HOST}

Recognition by the host that infection has occurred is required for the induction of defense responses (Dixon et al., 1994). Extensive studies of many different plant-pathogen interactions have shown that upon recognition of a pathogen, plants utilize a large arsenal of defense mechanisms to protect themselves. Inducible mechanisms of defense fall into four categories: 1) generation of signals (active oxygen species, ethylene, salicylic acid, jasmonates, and elicitors); 2) structural barriers (callose, cell wall proteins, cutin, suberin, lignin, phenolics, and waxes); 3) hypersensitive cell death; 4) inhibitors of pathogen growth (phytoalexins, PR proteins). Most, if not all, of the inducible defense responses are the result of transcriptional activation of specific genes (Kombrink and Sommisch, 1995).

Elicitors can be components of the microbial cell surface or they can require enzymatic activity of the host to be released. Pectolytic enzymes and their products induce ethylene in citrus (Baldwin and Biggs, 1988) and tomato fruit (Baldwin and Pressey, 1989, 1990). Ethylene regulates gene expression in both climacteric (Lelievre et al., 1997) and nonclimacteric (Alonso et al., 1995; Lelievre et al., 1997) fruit and leads to increased and decreased expression, depending on the particular gene in question. Medina-Suarez et al. (1997) reported that, during banana ripening, expression of a gene coding for a thaumatin-like antifungal protein was down-regulated during ripening. In a similar study Clendennen and May (1997) found that chitinase, endochitinase, $\beta$-1,3-glucanase, and thaumatin-like transcripts were abundant in ripening banana fruit.

Ethylene accelerates senescence and, as a consequence, the effect is generally an increase in decay development. In addition, infection of plant tissues leads to increases in ethylene evolution (Boller, 1991). The effects of ethylene on decay development have been well studied in citrus fruit, and the response varies with the pathogen in question. Ethylene treatment tends to decrease the severity of decay caused by wound pathogens, whereas it increases the incidence of stem-end rot caused by quiescent infections. The incidence of green mold caused by $P$. digitatum is reduced by exposure to $\approx 5 \mathrm{ppm}$ ethylene at $30^{\circ} \mathrm{C}$ and $90 \%$ to $96 \%$ relative humidity for 2 or $3 \mathrm{~d}$, as is commonly practiced for degreening of early-season fruit (Brown, 1973). Exposure of orange fruit to $1000 \mathrm{ppm}$ ethylene at $20{ }^{\circ} \mathrm{C}$ for 2 to $6 \mathrm{~d}$ prior to inoculation with $P$. italicum reduced fungal growth, as indicated by lesion diameter and glucosamine content (El-Kazzaz et. al., 1983), suggesting that ethylene was inducing defense responses in the host.

The incidence of stem-end rot caused by $D$. natalensis is substantially greater on ethylene-treated fruit than on nonethylene-treated fruit (Barmore and Brown, 1985). This effect of ethylene may be the result of changes in the host that render it more susceptible to the pathogen rather than a direct effect on the pathogen. Brown and Burns (1998) reported that the activity of abscission enzymes, polygalacturonase, and cellulase in the oranges was enhanced by treatment with ethylene, and treatment of abscission zones with purified PG and CX led to increased infection by Diplodia, indicating a role of these enzymes in facilitating infection. Labavitch (1998) suggested that ethyleneinduced PG activity in tomato fruit is related to decreased resistance to decay. However, results presented by Cooper et al. (1998) suggest that host PG is not related to pathogen susceptibility in tomato fruit.

Mullins et al. (2000) found that treatment of grapefruit with 1$\mathrm{MCP}$, an irreversible inhibitor of ethylene action, led to increased ethylene production in the absence or presence of $P$. digitatum infection, but did not affect the rate of disease development. Porat et. al. (1999) found that treatment of 'Shamouti' oranges with 1-MCP increased the amount of stem-end rot but reduced the amount of decay caused by Penicillium species.

The role of chitinase and glucanase in resistance of grapefruit has been suggested; however, results are not conclusive. Grapefruit have 
high levels of chitinase and low levels of glucanase activity when they are young and most resistant to decay (McCollum et al., 1997). During development, chitinase levels decrease and glucanase levels increase. Ultraviolet irradiation induces resistance to $P$. digitatum in grapefruit, and this is correlated with an increase in levels of chitinase proteins (Porat et al., 1999). Infection of grapefruit flavedo with $P$. digitatum resulted in the accumulation of ACC synthase, glucanase, and PAL transcripts, but not chitinase(Mullins et al., 2000; Mullins and McCollum, unpublished).

\section{FUTURE DIRECTIONS}

It is now well recognized that specific changes in gene expression induced in pathogens by their hosts, and in hosts in response to pathogen infection, are responsible for the development of decay or resistance. It is also evident that the interaction between host and pathogen is highly complex. Most studies of host-pathogen interactions conducted thus far have focused on single genes or gene products. Although tremendous strides have been made using this approach, utilizing a genomics approach and microarray technology (Aharoni et al., 2000; Reymond et al., 2000) to study host-pathogen interactions will no doubt provide greater insights. With greater understanding of the factors governing decay development and its corollary, resistance, it will be possible to develop strategies based on natural mechanisms of resistance to reduce decay and thereby reduce reliance on synthetic fungicides.

\section{Literature Cited}

Aharoni, A., L.C.P. Keizer, H.J. Bouwmeester, Z. Sun, M. Alvarez-Huerta, H.A. Verhoeven, J. Blaas, A.M.M.L. van Houwelingen, R.C.H. De Vos, H. van der Voet, R.C. Jansen, M. Guis, J. Mol, R.W. Davis, M. Schena, A.J. van Tunen, and A.P. O'Connell. 2000. Identification of the SAAT gene involved in strawberry flavor biogenesis by use of DNA microarrays. Plant Cell 12:647-661.

Alonso, J.M., J. Chamarro, and A. Granell. 1995. Evidence for the involvement of ethylene in the expression of specific RNAs during maturation of the orange, a nonclimacteric fruit. Plant Mol. Biol. 29:385-390.

Baldwin, E.A. and R.H. Biggs. 1988. Cell-wall lysing enzymes and products of cell-wall digestion elicit ethylene in citrus. Physiol. Plant. 73:58-64.

Baldwin, E.A. and R. Pressey. 1988. Tomato polygalacturonase elicits ethylene production in tomato fruit. J. Amer. Soc. Hort. Sci. 113:92-95.

Baldwin, E.A. and R. Pressey. 1990. Exopolygalacturonase elicits ethylene production in tomato. HortScience 25:779-780.

Barmore, C.R. and G.E. Brown. 1985. Influence of ethylene on increased susceptibility of oranges to Diplodia natalensis. Plant Dis. 69:228-230.

Boller, T. 1991. Ethylene in pathogenesis and disease resistance. In: A.K. Mattoo and J.C. Suttle (eds.). The plant hormone ethylene. CRC, Boca Raton, Fla.

Bostock, R.M., S.M. Wilcox, G. Wang, and J.E. Adaskaveg. 1999. Suppression of Monilinia fructicola cutinase production by peach fruit surface phenolic acids. Physiol. Mol. Plant Path. 54:37-50.

Brown, G.E. 1973. Development of green mold in degreened oranges. Phytopathology 63:1104-1107.

Brown, G.E. and H.S. Lee. 1993. Interactions of ethylene with citrus stem-end rot caused by Diplodia natalensis. Phytopathology 83:1204-1208.

Brown, G.E. and J.K. Burns. 1998. Enhanced activity of abscission enzymes predisposes oranges to invasion by Diplodia natalensis during ethylene degreening. Postharvest Biol. Tech. 14:217-227.

Burchill, R.T. and R.B. Maude. 1986. Microbial deterioration in stored fresh fruit and vegetables. Outlook on agriculture. 15:160-166.

Clendennen, S.K. and G.D. May. 1997. Differential gene expression in ripening banana fruit. Plant Physiol. 115:463-469.

Cooper, W. M. Bouzayen, A. Hamilton, C. Barry, S. Rossall, and D. Grierson. 1998. Use of transgenic plants to study the role of ethylene and polygalacturonase during infection of tomato fruit by Colletotrichum gloeosporioides. Plant Pathol. 47:308-316.

Dickman, M.B., G.K. Podila, and P.E. Kolattukundy. 1989. Insertion of cutinase gene into a wound pathogen enables it to infect intact host. Nature 342:446-448.

Dixon, R.A. and C.J. Lamb. 1990. Molecular communication in interactions between plants and microbial pathogens. Ann. Rev. Plant Physiol. Mol. Biol. 41:339-367.

Dixon, R.A., M.J. Harrison, and C.J. Lamb. 1994. Early events in the activation of plant defense responses. Ann. Rev. Phytopathol. 32:479-501.

Eckert, J.W. 1975. Postharvest diseases of fresh fruits and vegetablesEtiology and control. In: N.F. Haard and D.K. Salunkhe (eds.). Postharvest biology and handling of fruits and vegetables. AVI.

Eckert, J.W. and M. Ratnayake. 1983. Host-pathogen interactions in postharvest disease. In: Morris Lieberman (ed.). Postharvest physiology and crop preservation. Plenum Press, New York.

Eckert, J.W. and M. Ratnayake. 1994. Role of volatile compounds from wounded oranges in induction of germination of Penicillium digitatum conidia. Phytopathology 84:746-750.

El-Kazzaz, M.K., A. Chordas, and A.A. Kader. 1983. Physiological and compositional changes in orange fruit in relation to modification of their susceptibility to Penicillium italicum by ethylene treatment. J. Amer. Soc. Hort. Sci. 108:618-621.

Flaishman, M.A. and P.E. Kolattukudy. 1994. Timing of fungal invasion using host's ripening hormone as a signal. Proc. Nat. Acad. Sci. 91:6579-6583.

Hahn, M.G. 1996. Microbial elicitors and their receptors in plants. Ann. Rev. Phytopathol. 34:387-412.

Hwang, C.S., M.A. Flaishman, and P.E. Kolattukudy. 1995. Cloning of a gene expressed during appressorium formation by Colletotrichum gloeosporioides and a marked decrease in virulence by disruption of this gene. Plant Cell 7:183-193.

Keen, N.T. 1992. The molecular biology of disease resistance. Plant Mol. Biol. 19:109-122.

Knogge, W. 1996. Fungal infection of plants. Plant Cell 8:1711-1722.

Kombrink, E. and I.E. Somssich. 1995. Defense responses of plants to pathogens. Adv. Bot. Res. 21:1-34.

Labavitch, J.M. 1998. Fruit ripening and defense against pathogens-Loss of resistance or gain of susceptibility?, p. 53-59. In: G.I. Johnson, E. Highley, and D.C. Joyce (eds.). Disease resistance in fruit. ACIAR Proc. Ser. 80.

Labavitch, J.M., L.C. Greve, A.L.T. Powell, A.B. Bennett, and K.R. Sharrock. 1998. Polygalacturonase inhibitor proteins-Do they contribute to fruit defense against fungal pathogens?, p. 53-59. In: G.I. Johnson, E. Highley, and D.C. Joyce (eds.). Disease resistance in fruit. ACIAR Proc. Ser. 80.

Lelievre, J.M., A. Latche, B. Jones, M. Bouzayen, and J.C. Pech. 1997. Ethylene and fruit ripening. Physiol. Plant. 101:727-739.

McCollum, T.G., H. Doosdar, R.T. Mayer, and R.E. McDonald. 1997. Characterization of chitinases and $\beta$-1,3-glucanases in grapefruit flavedo during fruit development. Physiol. Plant. 99:486-494.

Medina-Suarez, R., K. Manning, J. Fletcher, J. Aked, C.R. Bird, and G.B. Seymour. 1997. Gene expression in the pulp of ripening bananas. Plant Physiol. 115:453-461.

Mullins, E.D. T.G. McCollum, and R.E. McDonald. 2000. Consequences on ethylene metabolism of inactivating the ethylene receptor sites in diseased non-climacteric fruit. Postharvest Biol. Tech. 19:155-164.

Pathak, V.N. 1997. Postharvest fruit pathology-Present status and future possibilities. Indian Phytopathol. 50:161-185.

Podila, G.K., L.M. Rogers, and P.E. Kolattukundy. 1993. Chemical signals from avocado fruit surface wax trigger germination and appressorium formation in Colletotrichum gloeosporioides. Plant Physiol. 103:267-272.

Porat, R., A. Lers, S. Dori, L. Cohen, B. Weiss, A. Ddaus, C.L. Wilson, and S. Droby. 1999. Induction of chitinase and $\beta-1,3$-endoglucanase proteins by UV irradiation and wounding in grapefruit peel tissue. Phytoparasitica 27:233-238.

Porat, R., B. Weiss, L. Cohen, A. Daus, R. Goren, and S. Droby. 1999. Effects of ethylene and 1-methylcyclopropene on the postharvest qualities of 'Shamouti' oranges. Postharvest Biol. Tech. 15:155-163.

Prusky, D. 1996. Pathogen quiescence in postharvest diseases. Ann. Rev. Phytopathol. 34:413-434.

Prusky, D. 1998. Mechanisms of resistance of fruits and vegetables to postharvest diseases, p. 19-33. In: G.I. Johnson, E. Highley, and D.C. Joyce (eds.). Disease resistance in fruit. ACIAR Proc. Ser. 80.

Ragsdale, N.N. and H.D. Sisler. 1994. Social and political implications of managing plant diseases with decreased availability of fungicides in the United States. Ann. Rev. Phytopathol. 32:545-557

Reymond, P., H. Weber, M. Damond, and E.E. Farmer. 2000. Differential gene expression in response to mechanical wounding and insect feeding in Arabidopsis. Plant Cell 12:707-719.

Sutton, T.B. 1996. Changing options for the control of deciduous fruit tree diseases. Ann. Rev. Phytopathol. 34:527-47.

ten Have, A., W. Mulder, J. Visser, and J.A.L. van Kan. 1998. The endopolygalacturonase gene Bcpg1 is required for full virulence of Botrytis cinerea. Mol. Plant Micro. Interact. 11:1009-1016.

van Kan, J.A.L., J.W. van't Kloster, C.A.M. Wagemakers, D.C.T. Dees, C.J.B. van der Vlugt-Bergmans. 1997. Cutinase A of Botrytis cinerea is expressed, but not essential during penetration of gerbera and tomato. Mol. Plant Micro, Interact. 10:30-38.

Walton, J.D. 1994. Deconstructing the cell wall. Plant Physiol. 104:1113-1118.

Wattad, C., D. Kobiler, A. Dinoor, and D. Prusky. 1997. Pectate lyase of Colletotrichum gloeosporioides attacking avocado fruits: cDNA cloning and involvement in pathogenicity. Physiol. Mol. Plant Path. 50:197-212. 